\title{
Preliminary investigation on the variation of the nucleolar organizer region in the breeding chinchilla karyotype ${ }^{1)}$
}

\author{
MARTA KUCHTA-GŁADYSZ, AGNIESZKA OTWINOWSKA-MINDUR*, PIOTR NIEDBAŁA**, \\ OLGA SZELESZCZUK, JOANNA GŁOWACKA
}

\author{
Institute of Veterinary Sciences, University of Agriculture, al. Mickiewicza 24/28, 30-059 Kraków, Poland \\ *Department of Genetics and Animal Breeding, University of Agriculture, al. Mickiewicza 24/28, 30-059 Kraków, Poland \\ **Institute of Animal Sciences, University of Agriculture, al. Mickiewicza 24/28, 30-059 Kraków, Poland
}

\section{Kuchta-Gładysz M., Otwinowska-Mindur A., Niedbała P., Szeleszczuk O., Głowacka J. Preliminary investigation on the variation of the nucleolar organizer region in the breeding chinchilla karyotype}

\section{Summary}

The objective of this study was to determine the variation in the number and size of nucleolar organizer regions (NOR) in the chinchilla karyotype. The study was performed with 12 standard chinchillas of two different lines. NORs were visualized on chromosome preparations by Ag-NOR silver staining. Four NOR size classes (I-IV) were determined on the basis of the results obtained, ranging from 0.070 (class I) to 0.229 (class IV). The mean NOR size was $0.144 \mu \mathrm{m}^{2}\left(\mathrm{SD}=0.031 \mu \mathrm{m}^{2}\right)$ and fell within class II (from 0.101 to $\left.0.150 \mu \mathrm{m}^{2}\right)$. Differences in the relative silver deposit area between the NOR-bearing pair of chromosomes were significant for 3 animals $(P<0.01)$ and for 1 animal $(P<0.05)$. The mean number of NORs in the animals ranged from 1.4 to $2.0(\mathrm{SD}=\mathbf{0 . 0 0 - 0 . 5 5 )}$. It was lower for chinchillas from central Poland $(\mathbf{1 . 5 3} \pm \mathbf{0 . 5 0})$ compared to those from southern Poland (1.68 $\pm \mathbf{0 . 4 8})$, with no significant differences $(P>0.05)$. The variation observed in the $N O R$ size and number in the chinchilla karyotype indicates the occurrence of NOR polymorphism in the population.

Keywords: nucleolar organizer region (NOR), chromosome markers, chinchilla

The chinchilla belongs to the order Rodentia (family Chinchillidae, genus Chinchilla) and comes from South America, living freely in the Andes mountain range $(15,31,32)$. Owing to the high value of their fur, chinchillas were almost exterminated in their natural habitat, which is why the small chinchillas living in the wild are now strictly protected $(6,15)$. This species has been covered by a conservation program through genetic resources cryobanking (37), while the breeding of chinchillas for fur production and as pets also protects the species.

A diploid chromosome number of $2 \mathrm{n}=64$ was found in the somatic cells of farmed chinchillas $(12,19,20)$. First reports on the karyotype structure in chinchillas indicate that it consists of 62 autosomes, including 38 metacentric, 20 submetacentric, and 4 subtelocentric (12). Kuchta-Gładysz et al. (20), using the position of centromeres as an evaluation criterion, observed that the karyotype of $C h$. lanigera shows little morphologi-

\footnotetext{
${ }^{1)}$ The studies were supported by the Mission-Related Research: DS-3253.
}

cal variation. It consists exclusively of 59 metacentric and 5 submetacentric chromosomes. In addition, they showed the sites of $45 \mathrm{~S}$ rDNA and telomeric sequences (TTAGGG) in the chinchilla genome and determined the G-banding pattern for this species. The X chromosome is the largest metacentric chromosome in the karyotype and represents a duplicate-type X chromosome, while the Y chromosome is one of the smallest chromosomes in the chinchilla karyotype and is a submetacentric type $(12,14,20)$. What is more, silver nitrate staining (Ag-NOR) demonstrated the presence of two active nucleolar organizer regions (NOR) within the first pair of metacentric autosomes (18).

For over a decade, scientists have focused their research on cell ultrastructure, including the nucleolus of the NOR (nucleolar organizer region). Nucleolar organizer regions are parts of chromosomes that contain rRNA coding genes $(5.8 \mathrm{~S}, 18 \mathrm{~S}, 28 \mathrm{~S})$. Based on these genes, nucleoli can form during interphase (34). Nucleolar organizer regions can show polymorphism in 
the same way as constitutive heterochromatin regions (26). The polymorphic forms of NOR and of C-bands in chromosomes generally serve as chromosomal markers. Such molecular markers are currently used for mapping the genes controlling economically important traits and for gene linkage analysis. Determination of these markers in the karyotype of a species is an important component of describing the physical map of the genome $(1,16)$. It is also believed that the number and size of NORs is a marker of cell proliferative activity and provides important information about cell kinetics, which is associated with its sensitivity to different factors, including environmental pollution or oncological therapies (39). The number and size of NORs reflects cellular activity, which is manifested by protein synthesis intensity. The nucleoli themselves are some of the least stable cell organelles, whose morphology and ultrastructure vary according to the species, type of the cell, degree of its differentiation, and cell cycle, responding quickly to different physiological and pathological conditions. The occurrence of NORs and changes in their expression have been investigated over the years also in breeding animals. The experiments focused mainly on the economically important traits of those species. Numerous such studies have been performed in horses (35), cattle (17), pigs (16), and goats (2).

The aim of our study was to determine the individual and population variation of nucleolar organizer regions (NOR) in the farm chinchilla karyotype.

\section{Material and methods}

The experiment was conducted on 25 standard farm chinchillas originating from southern and central Poland. The animals were kept in standard cages. They were fed a mixture of TMR in the form of granules plus hay. The group of experimental animals were the same age ( 9 months). Owing to a low mitotic index, 12 individuals were selected for further cytogenetic analysis ( 6 females and 6 males). A total of 120 preparations were analyzed. Fifty complete, well-spread and well-stained metaphase plates (Ag-NOR) were chosen for each animal. Tests were conducted on bone marrow isolated postmortem from the femur, which was collected from 12 animals after slaughter for skinning.

Chromosome preparations from bone marrow cells were made by the method of Tjio and Whang (36). The number and sites of NORs were identified by the classic silver staining (Ag-NOR) method (13). Photographic documentation was made from photomicrographs taken with a Nikon Eclipse 80 i microscope coupled with a Nikon Digital Sight DS-U1 digital camera. Image analysis software (MultiScan Base 6.08, MultiScan,
Poland) was used to measure the ratio of the silver deposit area to the whole chromosome-bearing NOR area in $\mu \mathrm{m}^{2}$. Each measurement was repeated twice.

The effects of homolog types and the region were examined using an SAS package (27). The differences between NOR areas were analyzed by the t-Student test. The differences between the number of NORs were analyzed using the nonparametric Wilcoxon-Mann-Whitney test. The differences were analyzed at $P<0.05$ and $P<0.01$. Additionally, the NOR area was analyzed for both homolog types separately for each animal.

\section{Results and discussion}

Two active nucleolar organizer regions (NORs) were detected on the shorter arms of the first and longest autosomes (1p). The mean relative values for the NOR area in the chromosomes were divided into four size classes on the basis of the results obtained (Tab. 1). The different NOR size variants are shown in Fig. 1. The mean NOR size was $0.144 \mu \mathrm{m}^{2}\left(\mathrm{SD}=0.031 \mu \mathrm{m}^{2}\right)$ and fell within class II (from 0.101 to $0.150 \mu \mathrm{m}^{2}$ ).

The characteristics of the analyzed population in terms of the size and number of NOR silver deposits are presented in Tab. 2. Differences in the relative area of silver deposits between the NOR-bearing pair of chromosomes were significant for animals $\mathrm{H} 2, \mathrm{H} 7$,
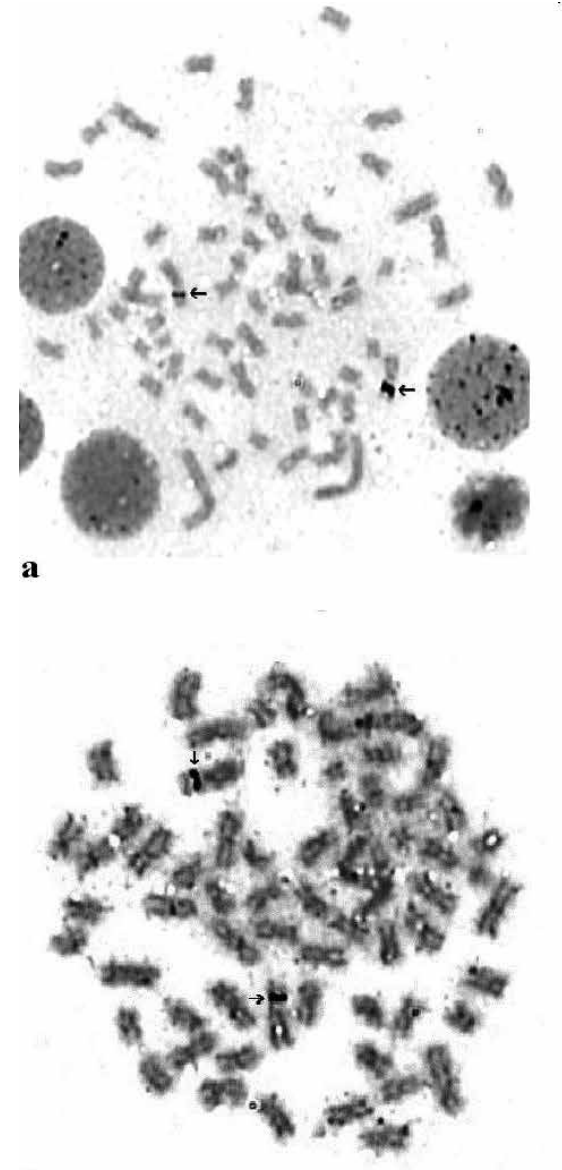

c

Fig. 1. Four NOR size classes in the chinchilla karyotype: a) class I: from 0.050 to $0.100 \mu \mathrm{m}^{2}$; b) class II: from 0.101 to $0.150 \mu \mathrm{m}^{2}$; c) class III: from 0.151 to $0.200 \mu \mathrm{m}^{2}$; d) class IV: from 0.201 to $0.250 \mu \mathrm{m}^{2}$. Arrows indicate NOR chromosomes. Scale bar $=10 \mu \mathrm{m}$
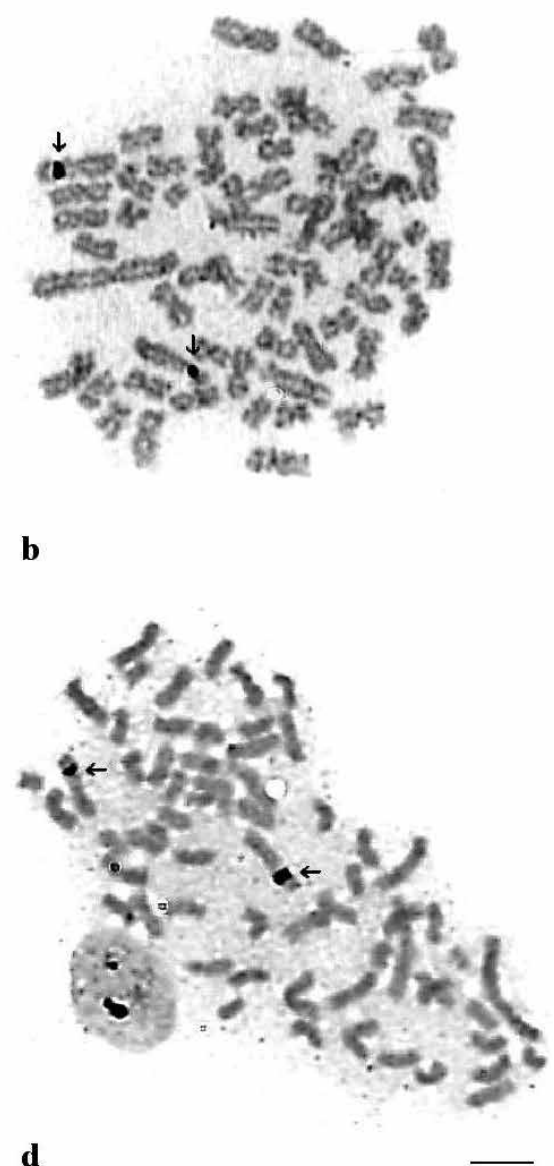

d 
and H11 $(P<0.01)$, and for animal H10 $(P<0.05)$. In the remaining animals, one of the homologs was also greater on average than the other, but the differences were not significant $(P>0.05)$. These results are indicative of marked differences in the transcription level of NOR areas in these animals. The variation in the size and number of NORs in the chinchilla karyotype may suggest that the population is genetically predisposed to NOR size polymorphism, but this should be evaluated in terms of generations and for a greater number of animals. The mean number of NORs in the animals studied here ranged from 1.4 to $2.0(\mathrm{SD}=0.00-0.55)$. In two animals (H1 and H4), the number of NORs showed no variation and equaled 1 .

In 4 out of 12 animals studied (H1, H3, H5 and H9), the NOR-bearing pair of chromosomes had silver deposits of the same size class (Tab. 2). In the popula-

Tab. 1. Categories of NOR area size and percentages of animals in each category

\begin{tabular}{|c|c|c|c|c|c|}
\hline \multirow{2}{*}{ Size category } & \multicolumn{2}{|c|}{ NOR area $\left(\mu \mathrm{m}^{2}\right)$} & \multicolumn{3}{c|}{ Percentage of animals } \\
& From & To & Homolog 1 & Homolog 2 & Total \\
\hline I & 0.050 & 0.100 & 0 & 25 & 17 \\
II & 0.101 & 0.150 & 33 & 58 & 33 \\
III & 0.151 & 0.200 & 42 & 8 & 42 \\
IV & 0.201 & 0.250 & 25 & 8 & 8 \\
\hline
\end{tabular}

tion, analyzed in terms of the mean relative NOR size area, $17 \%$ of the animals belonged to class I, $33 \%$ to class II, $42 \%$ to class III, and only $8 \%$ to class IV (Tab. 1). Most of the chromosomes analyzed (45\%) were of class II, $25 \%$ of class III, $17 \%$ of class IV, and only $13 \%$ of class I.

Table 3 presents differences in the areas of silver deposits on the chromosomes of chinchillas coming from two regions of Poland. In animals from central Poland, the silver deposit area on both homologs $\left(0.170\right.$ and $\left.0.131 \mu \mathrm{m}^{2}\right)$ was greater than in animals from southern Poland $\left(0.150\right.$ and $\left.0.114 \mu \mathrm{m}^{2}\right)$, with no significant differences in the NOR size $(P>0.05)$. The mean number of NORs in the chinchillas from central Poland $(1.53 \pm 0.50)$ was lower than in the animals from southern Poland $(1.68 \pm 0.48)$, and there were no significant differences $(P>0.05)$ in the mean number of silver deposits between the chinchillas from the two regions.

The nucleolar organizer region is a chromosomal segment in which rDNA loops contain rRNA genes responsible for the production and function of ribosomal units in mammals. The NOR is associated with nucleolus formation (21). NOR genes

Tab. 2. Characteristics (means and standard deviations - SD) of silver deposits (NOR) in 12 chinchillas

\begin{tabular}{|c|c|c|c|c|c|c|c|c|c|c|c|}
\hline \multirow{3}{*}{ Animal } & \multicolumn{3}{|c|}{ Homolog 1} & \multicolumn{3}{|c|}{ Homolog 2} & \multicolumn{3}{|c|}{ Total } & \multirow{2}{*}{\multicolumn{2}{|c|}{ Number of NORs }} \\
\hline & \multicolumn{2}{|c|}{ NOR area $\left(\mu \mathrm{m}^{2}\right)$} & \multirow{2}{*}{$\begin{array}{c}\text { Size } \\
\text { category1) }\end{array}$} & \multicolumn{2}{|c|}{ NOR area $\left(\mu \mathrm{m}^{2}\right)$} & \multirow{2}{*}{$\begin{array}{c}\text { Size } \\
\text { category }{ }^{1)}\end{array}$} & \multicolumn{2}{|c|}{ NOR area $\left(\mu \mathrm{m}^{2}\right)$} & \multirow{2}{*}{$\begin{array}{c}\text { Size } \\
\text { category }{ }^{1)}\end{array}$} & & \\
\hline & Mean & SD & & Mean & SD & & Mean & SD & & Mean & SD \\
\hline H1. & 0.228 & 0.063 & IV & 0.214 & 0.059 & IV & 0.221 & 0.061 & IV & 2.00 & 0.00 \\
\hline H2. & $0.164^{* *}$ & 0.011 & III & $0.076^{* *}$ & 0.014 & I & 0.120 & 0.013 & II & 1.40 & 0.55 \\
\hline H3. & 0.112 & 0.017 & II & 0.103 & 0.023 & II & 0.108 & 0.020 & II & 1.60 & 0.52 \\
\hline H4. & 0.165 & 0.027 & III & 0.143 & 0.031 & II & 0.154 & 0.029 & III & 1.00 & 0.00 \\
\hline H5. & 0.169 & 0.029 & III & 0.152 & 0.025 & III & 0.161 & 0.027 & III & 1.17 & 0.38 \\
\hline H6. & 0.161 & 0.026 & III & 0.146 & 0.027 & II & 0.154 & 0.027 & III & 1.43 & 0.53 \\
\hline H7. & $0.229 * *$ & 0.035 & IV & $0.108^{* *}$ & 0.040 & II & 0.169 & 0.038 & III & 1.60 & 0.52 \\
\hline H8. & 0.107 & 0.029 & II & 0.090 & 0.025 & I & 0.099 & 0.027 & I & 1.86 & 0.36 \\
\hline н9. & 0.137 & 0.020 & II & 0.122 & 0.025 & II & 0.130 & 0.023 & II & 1.58 & 0.51 \\
\hline H10. & $0.202^{*}$ & 0.035 & IV & $0.149 *$ & 0.050 & II & 0.176 & 0.043 & III & 2.00 & 0.00 \\
\hline H11. & $0.127^{* *}$ & 0.026 & II & $0.070^{* *}$ & 0.027 & I & 0.099 & 0.027 & I & 1.63 & 0.52 \\
\hline H12. & 0.157 & 0.039 & III & 0.132 & 0.030 & II & 0.145 & 0.035 & II & 1.60 & 0.55 \\
\hline Total & 0.163 & 0.030 & III & 0.125 & 0.031 & II & 0.144 & 0.031 & II & 1.57 & 0.50 \\
\hline
\end{tabular}

Explanations: ${ }^{1)} \mathrm{I}$ - from 0.050 to 0.100 , II - from 0.101 to 0.150 , III - from 0.151 to 0.200 and $\mathrm{IV}-$ from 0.201 to $0.250 \mu \mathrm{m}^{2}$;

* - values within the animal (in one row) differ at $P<0.05$; ** - values within the animal (in one row) differ at $P<0.01$

Tab. 3. Mean and standard deviations (SD) of silver deposits (NOR), by region

\begin{tabular}{|l|c|c|c|c|c|c|c|}
\hline \multirow{2}{*}{ Region } & \multirow{2}{*}{$\begin{array}{c}\text { Number of } \\
\text { animals }\end{array}$} & \multicolumn{2}{|c|}{ NOR area $\left(\mu \mathrm{m}^{2}\right)$} & \multicolumn{3}{c|}{ Number of NORs } \\
& & Mean & SD & Mean & SD & Mean & SD \\
\hline Central Poland & 8 & 0.170 & 0.030 & 0.131 & 0.031 & 1.53 & 0.50 \\
South Poland & 4 & 0.150 & 0.029 & 0.114 & 0.033 & 1.68 & 0.48 \\
Total & 12 & 0.163 & 0.030 & 0.125 & 0.031 & 1.57 & 0.50 \\
\hline
\end{tabular}


are generally located in the secondary constriction of the chromosome, which is why it is commonly identified by detecting the constriction visible during mitosis on metaphase chromosomes in the form of a constricted region of lower electron density. In the animal karyotype, the NOR is usually detected by ammoniacal silver staining (Ag-NOR technique). This method is used to detect sites on chromosomes that only contain active NOR regions as well as specific acidic chromatin proteins associated with rRNA genes $(21,39)$. Staining results in black silver deposits located near the chromatids (34). An alternative method to determine NORs in the genome is fluorescence in situ hybridization (FISH). Studies on different species show that Ag-NOR staining sites correspond to ribosome gene sites identified by FISH (26). In the present study, NOR variation in the chinchilla karyotype was analyzed by the Ag-NOR technique.

The number and position of NORs on chromosomes is a species-specific trait that ranges widely from 2 (e.g. nutria) to 56 (degu) and bears no relation to the diploid chromosome number of $2 n(4,26)$. The Ag-NOR detection of NORs on chromosomes in all the animals under study revealed the presence of one pair of metacentric autosomes (NOR chromosomes). The organizer regions were located on the $\mathrm{p}$ arm of chromosomes, which is consistent with the findings of Kuchta-Gładysz et al. (20), but contrasts with the results of Hong et al. (12).

Studies on different Mammalia species have demonstrated that the number of silver-staining NOR areas may vary within a species. In humans, it can vary from 5 to 10 , with clear individual, breed and population differences (9). Experiments with dogs showed that in the canine genome NORs are most often active on chromosome pairs $8,7,6,9,12$, and 10 (the order is based on the degree of transcriptional activity), and least often on pairs 5 and 11 (25). Similar individual differences in the number of rDNA in NOR chromosomes were also observed in pigs (23), mice (33), rats (3), the Cavidae family (11), cattle (30), the Cervidae family (10), and horses (40). The population polymorphism of NORs was found in rabbits (22) and in humans (24). In the present study, we observed individual and population variation in the size of signals on NOR chromosomes, and the results obtained indicate the presence of intrapopulation and intraindividual NOR size polymorphism. It should be noted that individual or group differences in the NOR size detected in the species analyzed did not concern the sex of the animals (28). Likewise in our study, performed on 6 females and 6 males, we observed no statistically significant sex-related differences in the number or size of NORs.

To date, NOR size classes in the chinchilla have not been determined. Nor has the polymorphism been investigated in this species. In the present study, we determined 4 NOR size classes in the chinchilla karyotype based on the differences in silver signals.
Similar studies were conducted on pigs (29), horses (17), and cattle (30). The studies cited below determined that the NOR size polymorphism was due to the varying lengths of the tandem repeats of DNA sequences, resulting from asymmetrical crossing-over caused by abnormal homologous chromosome pairing during meiosis. The NOR size variants that we determined were used as genetic markers useful for linkage analysis, breed characterization, the mapping of genes that control productive traits, determination of genetic distances, and the analysis of evolutionary relationships (7).

In all the animals studied here, one chromosome of the NOR-bearing pair was greater than the other, and the differences were statistically significant. The variable length linked to the variable size of NOR bands may result from differences in the length of the secondary constriction, which causes the chromosome with longer secondary constriction to produce more intensive silver signals compared to its homolog (41). This, in turn, causes variation in the transcriptional activity, which induces differences in the number of rRNA gene copies, visible after the detection of silver signals. A similar phenomenon was observed in rabbits, in which NOR activity showed significant differences between meat breeds and pelt breeds (26).

When analyzing the effect of the NOR size on the development of the chick embryo, Delany and Bloom (8) found a very small NOR size on the homologs, which was associated with embryo mortality. The deficiency of active rRNA genes disrupts the expression of genes during embryogenesis. A similar relationship was described in humans (35). In addition, Ag-NOR expression in humans was found to be related to the incidence of cancer. Nucleolar regions were reported as prognostic factors for pathological changes in many cancers, including those of the lungs, urinary bladder, prostate, colon, and lymphoid system $(5,39)$.

NOR regions are used as an experimental model for understanding the relationships between the chromosomal structure and the regulation and activity of rRNA genes in Eucaryota.

\section{References}

1.Andraszek K., Danielewicz A., Smalec E., Kapron M.: Identification of the nucleoli in domestic horse spermatocytes - preliminary investigations. Rocz. Nauk. PTZ 2010, 6, 13-21.

2. Andraszek K., Horoszewicz E., Smalec E.: Nucleolar organizer regions, satellite association and nucleolus of goat (Capra hircus). Arch. Tierzucht 2009, 52, 177-186.

3. Badenhorst D., Dobigny G., Adega F., Chaves R., O’Brien P., FergusonSmith M., Waters P., Robinson T.: Chromosomal evolution in Rattini (Muridae, Rodentia). Chromosome Res. 2011, 19, 709-727.

4. Berrios S., Fernandez-Donoso R., Pincheira J., Page J., Manterola M., Cerda M.: Number and nuclear localization of nucleoli in mammalian spermatocytes. Genetica 2004, 121, 219-228.

5. Bickham J., Rogers D.: Structure and variation of the nucleolus organizer region in turtles. Genetica 1985, 67, 171-184.

6. Cofré H., Marquet P. A.: Conservation status, rarity, and geographic priorities for conservation of Chilean mammals: an assessment. Biol. Conserv. 1999, $88,53-68$. 
7.Danielak-Czech B., Rejduch B., Babocz M.: Cytomolecular assay of size nucleolar organizer regions (NORs) polymorphism in Pietrain pigs. Annales Universitatis Mariae Curie-Skłodowska Lublin-Polonia 2011, 29, 33-38.

8. Delany M., Bloom S.: The effect of nucleolar size and ribosomal RNA gene copy number variation on the development of the chick embryo. Proc. $8^{\text {th }}$ North American Colloquium on Domestic Animal Cytogenetics and Gene mapping. Guelph, Canada 1993, 103-105.

9. Egan M. J., Cocker J.: Nucleolar organizer regions in pathology. Br. J. Cancer $1992,65,1-7$

10. Gallagher Jr D., Davis S., Donato M. de, Burzlaff J., Womack J., Taylor J., Kumamota A.: A molecular cytogenetic analysis of the tribe Bovini (Artiadactyla: Bovidae: Bovinae) with an emphasis on sex chromosome morphology and NOR distribution. Chromosome Res. 1999, 7, 481-492.

11. Gava A., Santos M., Quintela F.: A new karyotype for Cavia magna (Rodentia: Cavidae) from an estuarine island and C. aperea from adjacent mainland. Acta Theriologica 2012, 57, 9-14.

12. Hong J., Jiang S. D., Feng G. Y., Bei G. P., Zhang F.: A karyotype of Chinchilla laniger. Hereditas 1982, 24, 31-32.

13. Howell W. M., Black D. A.: Controlled silver-staining of nucleolus organizer regions with a protective colloidal developer: a 1-step method. Experientia 1980, 36, 1014-1015.

14. Hsu T. C., Benirschke K.: Rodentia, [in:] Hsu T. C., Benirschke K. (eds): An Atlas of Mammalian Chromosomes. Springer-Verlag, New York 1967, p. 1-2.

15. Jimenez J. E.: The extirpation and current status of wild chinchillas (Chinchilla lanigera and C. brevicaudata). Biol. Conserv. 1996, 77, 1-6.

16. KomisarekJ., Szydłowski M., Świtoński M., Kurył J.: The use of chromosomal markers for the identification of QTLs controlling fatting and carcass and meat quality traits in pigs. Hung. J. Anim. Prod. 1999, 48, 51

17. Kozubska-Sobocińska A., Stota E., Bugno M., Danielak-Czech B., Rejduch B.: Zastosowanie system MultiScan do oceny polimorfizmu chromosomów. Rocz. Nauk. Zoot. 1999, 26, 9-19.

18. Kuchta M., Grabowska-JoachimiakA., Szeleszczuk O., Niedbała P., Inicki T. Cytogenetic study of Chinchilla lanigera. Mol. Ann. Warsaw University of Life Sciences - SGGW, Animal Sci. 2011, 48, 138-139.

19. Kuchta M., Szeleszczuk O., Eysek B.: Profile of chromosome X in chinchilla (Chinchilla lanigera Mol.) karyotype. Scientifur 2008, 32, 78-79.

20. Kuchta-Gładysz M., Grabowska-Joachimiak A., Szeleszczuk O., Szczerbal I., Kociucka B., Niedbała P.: Karyotyping of Chinchilla lanigera Mol. (Rodentia, Chinchillidae). Caryologia 2015, DOI: 10.1080/00087114.2015.1032576.

21. Kunishio K., Ohmoto T., Matsuhisa T., Maeshiro T., Furuta T., Matsumoto K. The significance of nucleolar organizer region (Ag-NOR) score in predicting meningioma recurrence. Cancer 1994, 73, 2200-2205.

22. Martin-Deleon P., Fleming M., Petrosky D.: Patterns of silver staining in cells of six-day blastocytes and kidney fibroblast of the domestic rabbit. Chromosoma 1978, 67, 245-252.

23. Mellink C., Bosma A., De Hann N.: Variation in the size of Ag-NORs and fluorescent rDNA in situ hybridization signals in six breeds of domestic pig. Hereditas 1994, 120, 141-149.
24. Mikelsaar A., Ilus T.: Population polymorphism in silver staining of nucleolus organizer regions (NOR) in human acrocentric chromosomes. Human Genetics 1979, 51, 281-285

25.Pieńkowska A., Świtoński M.: Chromosomal localization and activity of nucleolar organizer regions in the dog (Canis familiaris). Genetics Selection Evolution 1998, 30, 79-84.

26. Pieńkowska A., Świtoński M.: Obszary jąderkotwórcze (NOR) u ssaków: wystepowanie i polimorfizm. Post. Biol. Kom. 1993, 20, 135-141.

27. SAS Institute Inc.: SAS/STAT 13.2 User's Guide. SAS Institute Inc. Cary, NC 2014.

28. Schwarzacher H., Wachler F.: Nucleolus organizer regions and nucleoli. Human Genetic 1983, 63, 9-99.

29. Słota E.: Polimorfizm chromosomów świni. Rocz. Nauk. Zoot.: Rozprawy Habilitacyjne 1998, 7, 5-59.

30. Stota E., Danielak-Czech B., Kozubska-Sobocińska A., Rejduch B., Bugno M. Identyfikacja markerów chromosomowych i możliwości ich wykorzystania w poszukiwaniu związków z cechami produkcyjnymi. Rocz. Nauk. Zoot. Supl. 2000, 5, 256-261.

31. Spotorno A. E., Valladares J. P., Marin J. C., Palma R. E., Zuleta C. R.: Molecular divergence and phylogenetic relationships of chinchillas (Rodentia: Chinchillidae). J. Mammal 2004a, 85, 384-388.

32. Spotorno A. E., Zuleta C. A., Valladares J. P., Deane A. L., Jiménez J. E. Chinchilla laniger. Mamm. Species 2004b, 758, 1-9.

33. Stitou S., Burgos M., Zurita F., Jimenez R., Sanchez A., Diaz de la Guardia R. Recent evolution of NOR-bearing and sex chromosomes of the North African rodent Lemniscomys barbarous. Chrom. Res. 1997, 5, 481-485.

34. Summer T.: Human genetics. Medical Center Report 1990, 187-205.

35. Świtoński M., Marcolla P., Pieńkowska A., Cholewiński G.: Preliminary investigation on inter-individual variation of the nucleolar organizer region (Ag-NORs) in the horse karyotype. Anim. Sci. Pap. Rep. 1994, 12, 15-19.

36. Tjio J. H., Whang J.: Chromosome preparations of bone marrow cells without prior in vitro culture or in vivo colchicine administration. Stain Technol. 1962, 37, 17-20.

37. Tovar H., Navarette F., Rodriguez L., Skewes O., Castro F.: Cold storage of biopsies from wild endangered native Chilean species in field conditions and subsequent isolation of primary culture cell lines. In Vitro Cellular Develop. Biol. - Animal 2008, 44, 309-320.

38. Treco F., Dias A.: Karyotypes of two species of the genus Pimelodus (Siluriformes, Pimelodidae). Folia Biologica 2009, 57, 43-48.

39. Urbanowicz I., Stacherzak-Pawlik J., Woźniak M.: AgNOR w rozrostach układu chłonnego. Adv. Clin. Exp. Med. 2005, 14, 1225-1235.

40. Wójcik E., Andraszek K., Smalec E.: Identyfikacja obszarów heterochromatynowych oraz rejonów jąderkotwórczych w chromosomach konia. Acta Sci. Pol. Zootech. 2009, 8, 41-54.

41.Zurita F., Sanchez A., Burgos M., Jimenez R., Diaz de la Guardio R.: Interchromosomal, intercellular and interindividual variability of NORs studied with silver staining and in situ hybridization. Heredity 1997, 78, 229-234.

Corresponding author: dr M. Kuchta-Gladysz, Al. Mickiewicza 24/28, 30-059 Kraków, Poland; e-mail: marta.kuchtagladysz@gmail.com 